\title{
Breaking Down the Walls to Stop the Violence: Prison Abolition through the Lens of Trauma Healing Joel Medina and Beth Caldwell
}

\section{INTRODUCTION}

Prisons and violence are inseparable. I was forced to fight for my survival as a prisoner in California penal institutions from the age of 16 until the age of 28. Violence, and the ever-present threat of violence, were the most consistent aspects of my living conditions while I was incarcerated. I was trapped in the middle of prison riots, surrounded by flying fists, shanks, blood, pepper spray and bullets. The first time I saw someone get stabbed, I was shocked. One moment, everything seemed calm. The next, blood was gushing out of a man's throat, covering his body and pooling onto the floor. Over time, I became accustomed to the smell of blood and to the graphic nature of the injuries that are common inside prison walls. I learned to be on high alert at all times because that was the only way to survive.

Exposure to such violent incidents over many years took a toll on me. Prisoners live in war-like situations. Not surprisingly, prisoners are affected by exposure to high levels of violence in much the same way as soldiers in war, often experiencing the effects of trauma long after the incidents have passed (Kupers, 2006). Unfortunately, the institutional design and the values that prisons are founded upon perpetual violence. Although violence within prisons is well documented and recognized, it persists in prisons throughout the world. On an international level, authorities have consistently failed to implement meaningful reforms to reduce the harms that prisons perpetuate and to address consistent failures to bring about rehabilitation within them (Papendorf, 2006; Piché and Larsen, 2010). Concerns regarding the apparent impossibility of effectively reforming the problems endemic to prisons have given rise to an international movement for prison abolition with strong roots in Norwegian criminology (Christie, 1997; Papendorf, 2006; Piché and Larsen, 2010). The prison abolition movement has been advanced by a series of International Conferences on Prison Abolition, the first of which was held in Toronto in 1983 (Piché and Larsen, 2010). Research regarding trauma healing supports the central tenets of the prison abolition movement, although the connections between trauma healing and prison abolition have not been previously explored in social science literature. 
When viewed through the lens of trauma healing, prisons must be abolished in order to stop the cycles of abuse and violence that they perpetuate. People experience emotional, physical and sexual trauma while in prison. Further, most prisoners have experienced high levels of trauma and violence prior to their incarceration (Gilligan, 1996; Kupers, 2006). When trauma is not treated or healed, it can result in both the internalization and the externalization of pain (Herman, 1997). Victims can turn into victimizers when their bodies house unhealed trauma. Therefore, trauma healing is an integral part of stopping cycles of violence and of decreasing future violent or criminal behavior. While necessary, such healing cannot possibly occur in the context of prisons.

This article takes a unique approach to the analysis of trauma in prisons by incorporating narrative examples from the first author's experiences as a prisoner who served twelve years in prison in the United States. The violent nature of prison life is described in an effort to draw attention to the disturbing realities of life behind bars. "Demasking the system" in this way is a strategy employed by Norwegian prison abolitionists in the 1970s, who had success with shifting public opinion regarding some penal practices (Papendorf, 2006). The narrative accounts in this article focus on traumatic incidents that the author experienced, with an emphasis on the systematic and institutionalized nature of trauma in the context of prisons. These examples are analyzed in the broader contexts trauma healing and prison abolition in order to highlight the impossibility of healing trauma inside prisons.

The first part of the article addresses specific aspects of trauma that are inherent to prisons, including: violence between prisoners; trauma inflicted by, and experienced by, prison guards; sexual assaults in prisons; and the psychological trauma inflicted by institutional policies. This section explores how the infliction of trauma is an unavoidable characteristic of prisons. The second part focuses on the need to help people to heal from the trauma they have experienced in their lives in order to stop cycles of abuse and victimization. This section incorporates research regarding the necessary preconditions for trauma healing and links the issue of trauma to literature regarding prison abolition. The article concludes by discussing need for an alternative paradigm for responding to crime that prioritizes healing and marginalizes the use of incarceration and other penal responses to crime. 


\section{PART I: TRAUMA IN THE CONTEXT OF PRISONS}

Trauma occurs when people experience an event that threatens their sense of safety, producing terror or feelings of helplessness (Yoder, 2005). It can be experienced through a wide range of events. People experience trauma at the individual level when they are attacked or injured, for instance. Those who victimize others may also experience trauma as a result of their participation. Trauma can be structurally induced, arising out of institutions and social structures. Although traumatic events affect everyone differently, an experience can generally be defined as traumatic if it "overwhelm[s] our usual ability to cope with and respond to threat" (ibid, p. 15).

In many ways, prisons are structured so as to create conditions that breed trauma (Reiman and Leighton, 2010). Many people, housed in overcrowded, small spaces and subjected to rituals of degradation, resort to violence as a means of self preservation in order to protect themselves physically or to preserve their identities by demanding respect (Kupers, 2006). The pervasive nature of traumatic experiences in the lives of people in prison highlights the inherent connection between trauma and prisons. It is virtually impossible to conceptualize a prison that does not create conditions that lead to trauma. Trauma is an inevitable component of a system of incarceration, and prison abolition is the only viable alternative to stop this state-sponsored infliction of violence, abuse and degradation.

\section{Violence between Prisoners}

Violent attacks between prisoners lead to experiences of trauma in a variety of ways. An event that threatens one's sense of safety and overwhelms the individual's capacity to respond to the threat constitutes a traumatic experience (Levine, 1997). An individual may experience trauma as a result of witnessing a violent incident, which is quite common for prisoners (Herman, 1997). Prisoners are exposed to trauma as both victims and perpetrators of violence towards other prisoners. People also experience trauma when they are personally physically attacked (ibid). In addition, trauma is experienced by those who inflict violence on others (Yoder, 2005). This phenomenon is referred to as "perpetrator trauma" and leads to more pronounced symptoms when the perpetrator engages in violence against his or her will (Herman, 2007). Prisoners are exposed to prolonged, frequent 
trauma as a result of the conditions of their incarceration. This is referred to as trauma of "captivity", the impacts of which are often more profound and long-term than for one-time traumatic incidents (ibid).

Violence was so pervasive in the prisons where I was housed that it was virtually impossible for me to trust anyone, including my own friends. I survived by becoming hyper vigilant. Violent attacks occurred regularly between different prison gangs, generally divided along racial lines in California prisons. These incidents frequently sparked riots. Even within racial groups or prison gangs, people frequently assaulted one another.

A prison riot is a profoundly traumatic experience that exposes people to the graphic violence of hand-to-hand combat that one would generally only expect in a battle. The trauma of the experience is exacerbated because there is no option to flee as prisoners are literally locked into enclosed spaces. According to trauma expert Peter Levine (1997), people are more likely to experience negative symptoms following exposure to traumatic events when they freeze or when they do not have the option to exercise the body's nature fight impulse. When one remains trapped or frozen, adrenaline and stress hormones become trapped in the body and are not discharged. This can create more long-term problems as a result of trauma.

Furthermore, given the dynamics between prisoners, people are forced to participate in violent acts even when they do not want to. Thus, people also experience the trauma of participating in inflicting violence. Being in the midst of a riot is chaotic. People attack each other from all sides, and a combination of fear and survival instincts seem to propel people to become more violent. As a prisoner in the midst of a riot, one must decide whether to comply with institutional orders to lie down on the ground. If one complies, there is a high probability of being attacked by other prisoners while lying on the ground. If one does not comply, he may be shot by prison authorities.

I was exposed to countless violent incidents while I was in prison. I observed another prisoner walk up to a man with whom I was talking and slice his throat with a razor blade. Blood spurted everywhere, covering his white t-shirt and splattering onto my arms as I jumped back in shock. I witnessed other people get stabbed on various occasions. Often, people were stabbed up to twenty times in a row, leading to bloody scenes and serious injuries. I recall hearing someone scream repeatedly from within the confines of his locked cell, pleading for his life as his cellmate stabbed him to death. I felt helpless hearing his pleas, as I was trapped within the 
confines of my cell as well, locked inside with no means of communicating with the guards.

Most prison assaults are meticulously planned and happen when one least expects it, which is why in prison people learn to expect the worst. This contributes to people living in a chronic state of hyper vigilance, which is difficult to move past even after one's time in prison is over. I remember a stabbing that occurred in the midst of a basketball game when two members of one team brutally attacked a player from the other team. I witnessed a man lying on the floor unconscious, with his head cracked open as other men continued to stomp and kick him as his limp body moved around like a rag doll. And my memories feel endless. There was a guy who commented on the picture of his friend's girlfriend who found himself getting his neck and face sliced an hour later because of his friend's extreme jealousy. I remember a man who had an overdue drug debt of 50 dollars. He died due to a fatal shank to his heart because of this debt. Exposure to such high levels of violence has a profound impact that often continues long after we are released.

Trauma experienced by those in captivity typically impairs one's ability to trust others and to have healthy relationships (Herman, 1997). According to Herman, prisoners learn to adapt to the difficult conditions of confinement by dissociating from the negative circumstances surrounding them. Over time, this state becomes internalized, and people become disconnected from other people, activities, thoughts, feelings and physical sensations. Dissociation is a symptom that persists after one's release from captivity, and has profound effects on people's emotional stability, relationships and identities.

\section{Correctional Officers}

The violence within prisons is so pervasive that it encompasses everyone within its limited boundaries, including those who work on the inside. Prison guards, referred to as Correctional Officers (COs) in California prisons, are on both the giving and receiving ends of violence. Prisoners experience trauma in relation to prison staff through verbal as well as physical interactions. The traumatic experience is heightened by the power differential. According to trauma expert Judith Herman (1997, p. 94), "during captivity, the victim cannot express her humiliated rage at the perpetrator, for to do so would jeopardize her survival'. Suppressing anger in response to abuse by authorities causes people to experience feelings of being trapped, where their adrenaline or emotions are rushing but they preventing from releasing the emotions. As 
discussed previously, this often leads to people developing more long-term symptoms of trauma (Levine, 1997).

I had numerous abusive experiences at the hands of COs. On one occasion, I was taken into a room for getting into a disagreement with a CO. I was verbally taunted and beaten while I was shackled. My body ached so much that I was not able to eat without excruciating pain for weeks after the incident. Over ten years later, I still experience shoulder pain as a result of the injuries I sustained. Trauma is also inflicted in more passive ways. For example, I saw an elderly man having a heart attack while a group of COs slowly sauntered towards him. He died because he did not receive timely medical attention. I witnessed a group of six prison guards beat and pepper spray a Samoan man for fifteen minutes without mercy, simply because he had refused to walk in a straight line. There were also COs who would purposely unlock people's cell doors in order to allow their enemies to enter their cells.

My friend had an argument with a guard one day. Later on that night, they came and picked him up from the dorm. I did not see him for two months. When he returned from the hole, he told me that they took him to a room and stripped him of all of his clothes. They slapped him, peppered sprayed him and beat him with their batons. In the 1990s, a highly publicized group of COs in California's Corcoran State Prison would stage gladiator-style fights between prisoners, betting on which one would win (Arax, 1996). Over fifty prisoners were injured during these fights, and seven were shot and killed by COs over an eight year period (ibid).

Abusive behaviour by prison guards appears to be virtually inevitable due to the institutional environments of prisons. Philip Zimbardo's infamous Stanford Prison Experiment demonstrates the power of the prison structure to impact the psychology and behaviour of individuals (see Zimbardo, 2007). In Zimbardo's experiment, young men were randomly assigned to play the roles of inmates and guards in a simulated prison. The people assigned to play guards became so abusive, and the people assigned to be prisoners were suffering from such emotional distress, that the experiment had to be discontinued after only six days. Zimbardo concluded that the environment of the "prison" and the roles assigned to the individual participants affected their behaviour in significant ways, causing the "guards" to become overly authoritarian, and in many cases abusive. Even six days in the simulated prison environment, where physical violence nowhere near as pervasive as in a regular prison environment, caused serious psychological reactions 
in many of the participants assigned to be prisoners. The findings of this study highlight serious problems with penal institutions; it would appear that abusive behaviour by authorities and psychological deterioration by prisoners are virtually inevitable in the environment of prisons.

In addition to perpetrating abuse, prison guards also experience trauma as victims - they are constant targets within prison walls. Prisoners throw bodily fluids such as semen, feces and urine at them, for example. I recall a CO who came to help my neighbour move to another cellblock. I watched through the window of my cell as the CO held my neighbour's TV in order to assist him. In response, my neighbour started slicing this man's face with a razor blade. Another time, I saw a nurse come to someone's cell to deliver medication, only to be punched in the face by the man she was trying to help.

The prison environment is structured so as to put both prisoners and prison guards in the positions of perpetrators and victims of violence. Abusive behaviour by prison staff is particularly problematic given their position of authority. Not only is exposing prisoners to violence at the hands of government authorities inhumane, it is also problematic because it will contribute to greater psychological problems and higher levels of violence among prisoners after their release.

\section{Sexual Assault}

Being sexually assaulted profoundly impacts victims' emotional and physical health. The prevalence of sexual assault within prisons is well documented. Recent surveys with incarcerated peoples in the United States revealed that 4.4 percent of prisoners reported being sexually victimized by another inmate or prison staff in the past 12 months (Beck and Harrison, 2010). 20 percent of male prisoners are victims of sexual assaults at some point during their incarceration (Struckman-Johnson et al., 1996, Struckman-Johnson and Struckman-Johnson, 2000).

My exposure to this problem was limited due to strictrules among Hispanic prisoners within California prisons. Any kind of homosexual activities were strictly forbidden according to this prisoner code and violations of this rule resulted in serious consequences. I do recall one night about an hour after the lights were turned off, loud screams echoed throughout the unit. A grown man was screaming, pleading "Please Stop!" as he was beaten and raped repeatedly by his cellmate. I also remember hearing about a young man in my building who was hog-tied and raped multiple times throughout 
the night by his cellmate. The next day, he walked to the program office and reported it. The victim was a seventeen-year-old in an adult prison. Research indicates that youth in adult prisons are particularly vulnerable to becoming victims of sexual assaults (Beck et. al, 2010). The prevalence of sexual assault within prisons is particularly problematic because many prisoners have experienced sexual abuse as children (Gilligan, 1996). They are thus at greater risk of suffering long-term psychological consequences because the abuse exacerbates the trauma they have already experienced.

\section{Trauma Inflicted by Institutional Policies and Actions}

High levels of violence between prisoners, abuse perpetrated by prison guards and sexual abuse within prisons are ultimately created by prison systems that are founded upon values that breed these conditions. Prisons throughout the world consistently fail to rectify these problems. Theoretically, abuse by prison guards could be curtailed by more meaningful monitoring, investigations and training. In practice, penal institutions do not seem to be capable of responding to problems of high levels of violence and abuse. Even where efforts have been made to minimize violence or abuse within prisons, the problems persist. Any efforts to change these conditions are impaired by the values and assumptions underlying the penal system. According to Norwegian criminologist Nils Christie (2000) punishment is the intentional infliction of harm. A penal system that is created with the purpose of inflicting harm is incapable of implementing reforms aimed at reducing the harm that the system inflicts upon prisoners. Such reforms would run counter to the fundamental values underlying the penal system. As such, abolishing prisons and the value structure underlying penal systems is the only viable way in which to address the institutional conditions that breed trauma in prisons.

In addition to creating conditions that create violence, institutional policies combine to create a system that inflicts psychological trauma that has profound implications on people's lives. Although less overt than physically abusing a prisoner, violence is enacted through prison policies that deliberately demean people or limit their autonomy more than necessary. The consistent deprivation of people's liberty and the way in which institutional actors arbitrarily, and often inhumanely, enforce the institutional rules, combine to create a sort of psychological torture that traumatizes prisoners. In Philip Zimbardo's prison experiment, for example, the individuals assigned 
to the role of "inmates" experienced severe psychological reactions due to authoritarian and demeaning treatment by "guards" (Zimbardo, 2007). Although the threat of physical violence was minimized in the experiment, the "inmates" nonetheless experienced trauma.

For many prisoners, relationships with family members are the most important aspect of their lives. Institutional policies regularly interfere with prisoners' family relationships as a form of punishment. This has a profound effect on people (Kupers, 2006). Many prisoners would rather be physically beaten by a guard than to lose the opportunity to visit with family members. During searches of people's cells, guards destroy photos of family members or make derogatory remarks about them. Prisoners are forced to decide between demonstrating their anger, which would likely result in further restrictions of privileges, or swallowing their emotions. This is a type of trauma (Herman, 1997). Other formal and informal disciplinary techniques include throwing away or hiding prisoners' mail or other personal belongings, as well as taking away commissary and visiting privileges. Each of these actions serves to further dehumanize a prisoner, stripping away the few aspects of one's life that bring happiness and a connection to the outside world.

\section{PART II: TRAUMA HEALING}

Traumatic experiences affect every individual differently. Some people internalize their reactions, while others display their symptoms through externalized behaviours. Despite these differences, there are some common reactions to traumatic experiences. This section explores some of the common symptoms of trauma and the benefits of approaches that focus on healing trauma. Successful practices of trauma healing are a promising tool for breaking cycles of violence, thereby reducing crime, improving community safety and healing lives. The preconditions for the implementation of such practices, however, stand in stark contrast to the conditions within prisons, rendering trauma healing impossible within the context of prisons.

\section{Impacts of Trauma}

When people experience trauma, physiological changes occur, triggering what has been termed a "fight-or-flight" response in the brain (Levine, 1997). 
This in turn leads to a state of heightened arousal in the body, characterized by an increased heart rate and rapid breathing. Drawing from observations of animals in the wild, Peter Levine explains that this response is designed to help people protect themselves when they are in danger. People who are able to use these survival mechanisms to fight off a danger or to run away from it are generally able to process the traumatic experience in a healthy way.

When people are unable to fight or flee from danger, such as in a situation where someone is physically trapped or is frozen by fear, trauma is more likely to have long-term effects (Yoder, 2005). As discussed previously, prison riots occur under circumstances that almost ensure that people experience this "frozen" state given that they are trapped within limited geographic boundaries with no options for escape. When trauma is trapped in the body, as in cases where people "freeze", it can cause long-term emotional and behavioral issues (Levine, 1997).

Some immediate responses to trauma include: hyper arousal, dissociation or denial, and feelings of profound helplessness or immobility (Herman, 1997; Levine, 2006). Common symptoms of trauma are flashbacks, nightmares, abrupt mood swings, shame, panic attacks, addictive behaviors, the inability to bond with others and physical pain or illness (Levine, 2006, pp. 17-18). Trauma can cause profound challenges to interpersonal relationships, to one's emotional state and ability to function.

According to trauma expert Judith Herman (1997, p. 35), hyper arousal occurs when "the human system of self-preservation seems to go onto permanent alert". In a state of hyper arousal, "the traumatized person startles easily, reacts irritably to small provocations, and sleeps poorly" (ibid). Upon my release from prison, I have experienced these symptoms. I feel the need to protect myself, for example, when someone walks towards me because I imagine that the person might stab me. I worry that someone might jump out of a car that drives past me to attack me. I am aware that my reactions to ordinary events are at times irrational, yet I am instinctively on-guard at all times.

\section{The Need for Trauma Healing}

Symptoms of trauma can be generally divided into two categories: internal and external. Internal symptoms of trauma include substance abuse, eating disorders, self-mutilation, depression, anxiety and physical ailments (Yoder, 2005 , p. 33). Trauma can trigger a cycle that ultimately leads a victim to become a victimizer due to unhealed wounds. External symptoms include 
domestic violence, child abuse, gang activity and aggressive behaviours (ibid). Experiencing ongoing trauma often causes people to become disconnected from themselves and from other people (Yoder, 2005). People seem to have an innate capacity to heal from trauma and that the experience can lead to profound transformations. Unfortunately, such healing cannot occur while people are incarcerated.

\section{The Impossibility of Trauma Healing in Prisons}

A growing body of literature discusses techniques for trauma healing that have brought about profound improvements in people's lives and in societies. Trauma healing generally incorporates a variety of practices, including mental, physical and spiritual components. However, being in a safe place is a prerequisite to trauma healing. According to trauma expert Carolyn Yoder $(2005$, p. 25), the most urgent need for trauma survivors is often for safety and security-physically, emotionally, and spiritually". Peter Levine (2006, p. 37) cautions people that prior to beginning the healing exercises he describes for people who have experienced trauma, readers must "find a safe place". Similarly, Judith Herman (1997) explains that there are three primary stages of recovery from trauma, and that the first stage focuses on establishing safety. People cannot progress to the next stages of the healing process without first establishing a sense of safety. Given the inherent violence and danger facing people in while they are incarcerated, creating this sense of safety is impossible within prisons.

Due to concerns regarding the inhumane and counterproductive nature of prisons, Norwegian criminologists such as Thomas Mathiesen have written about and advocated for prison abolition since the late 1960s (Papendorf, 2006). Such problems are not only present in prisons but are also entrenched within the broader penal system, including the courts, probation, police and the professionals involved in crime control systems (Christie, 1977; Piché and Larsen, 2010). Penal abolitionists envision social responses to crime that return responsibility for responding to conflicts to the individuals most directly involved, rather than vesting this responsibility with professionals and the state (Christie, 1977). Trauma healing would be much more possible in the context of such community-based responses to crime that focus on involving the parties directly involved in a conflict. Providing opportunities for people to heal from trauma is a crucial link to ending violence and abuse, yet it cannot occur within a punitive system that prioritizes incarceration. 


\section{CONCLUSION}

Violence creates more violence. Successful experiences with trauma healing provide hope for breaking cycles of violence within people and societies. However, state-sponsored penal institutions simultaneously inflict violence while also creating conditions under which it is impossible for people to heal from the trauma they have experienced both prior to and during their incarceration.

The prison abolition literature suggests, penal systems that are founded upon a commitment to retribution, revenge, and inflicting harm upon those subject to their control are incapable of being reformed to end prisoners' subjection to physical violence, sexual abuse and psychological trauma. Ultimately, continuing to expose prisoners to trauma and failing to create conditions in which they can heal causes harm to a much broader segment of society than prisoners themselves. Members of prisoners' families and communities are profoundly impacted when cycles of violence are allowed to continue. Alternative justice paradigms that directly involve victims, offenders and communities founded upon values such as restoration, reparation and healing have great potential to create healthier, safer, and more resilient people and communities (Christie, 1977, Zehr, 2005). Such

alternatives must be pursued in order to stop the cycles of abuse and violence endemic to penal institutions.

\section{REFERENCES}

Arax, Mark (1996) "Tales of Brutality Behind Bars", Los Angeles Times - August 21. Retrieved from < http://articles.latimes.com/1996-08-21/news/mn-36253_1_brutalprisons>.

Beck, Allen J. and Paige M. Harrison (2010) Sexual Abuse in Jails and Prisons Reported by Inmates, 2008-09, Washington (D.C.): Bureau of Justice Statistics. Retrieved from $<$ http://bjs.ojp.usdoj.gov/index.cfm?ty =pbdetail\&iid=2202>.

Beck, Allen, Paul Guerino and Paige M. Harrison (2010) Sexual Victimization in Juvenile Facilities Reported by Youth, 2008-2009, Washington (D.C.): Bureau of Justice Statistics. Retrieved from <http://bjs.ojp.usdoj.gov/index.cfm?iid= $2113 \&$ ty $=$ pbdetail $>$.

Christie, Nils (2000) Crime Control as Industry: Towards Gulags, Western Style (third edition), New York: Routledge.

Christie, Nils (1977) "Conflicts as Property", British Journal of Criminology, 17(1): 1-15.

Gilligan, James (1996) Violence: Reflections on a National Epidemic, New York: Vintage Books. 
Herman, Judith L. (1997) Trauma and Recovery, New York: Basic Books.

Kupers, Terry A. (2006) "How to Create Madness in Prison", in David Jones (ed.), Humane Prisons, Oxford: Radcliffe Publishing.

Levine, Peter A. (2006) Healing Trauma, Boulder: Sounds True, Inc.

Levine, Peter A. (1997) Waking the Tiger, Berkeley (CA): North Atlantic Books.

Papendorf, Knut (2006) "'The Unfinished' Reflections on the Norweigian Prison Movement", Acta Sociologica, 49(2): 127-137.

Piché, Justin and Mike Larsen (2010) "The Moving Targets of Penal Abolitionism: ICOPA, Past, Present and Future", Contemporary Justice Review, 13(4): 391-410.

Struckman-Johnson, Cindy and David Struckman-Johnson (2000) "Sexual Coercion Rates in Seven Midwestern Prison Facilities for Men", The Prison Journal, 80(4): 379-390.

Struckman-Johnson, Cindy, David Struckman-Johnson, Lila Rucker, Kurt Bumby and Stephen Donaldson (1996) "Sexual Coercion Reported by Men and Women in Prison", Journal of Sex Research, 33(2): 67-76.

Reiman, Jeffrey and Paul Leighton (2010) The Rich Get Richer, the Poor Get Prison (ninth edition), Toronto: Nelson.

Yoder, Carolyn (2005) The Little Book of Trauma Healing, Intercourse (PA): Good Books.

Zehr, Howard (2005) Changing Lenses: A New Focus for Criminal Justice (third edition), Scottsdale (PA): Herald Press.

Zimbardo, Phillip (2007) The Lucifer Effect, New York: Random House.

\section{ABOUT THE AUTHORS}

Joel Medina spent 12 years in California prisons and is grateful to have the opportunity to reflect upon his experiences. He earned his AA degree while in prison from Palo Verde College and is currently working towards completing a BA degree.

Beth Caldwell is an attorney and a social worker with a passion for social justice. She earned a JD and MSW from UCLA and currently works as a law professor. 